\title{
Researching Design Fiction With Design Fiction
}

\author{
Joseph Lindley \\ HighWire Centre for Doctoral Training \\ Lancaster University \\ joseph.lindley@gmail.com
}

\begin{abstract}
The term design fiction was first used in 2005 by Bruce Sterling [18:30] and in 2009 Julian Bleecker built on the idea by combining it with various other characterisations [cf. 1,2,10] and catalysed a step change in design fiction discourse. Since then design fiction has gained significant traction across academic contexts; at symposia and conference events; and through its practice within commercial design studios and industry. Despite becoming a popular way of framing speculative design, the characterisation of design fiction as research approach still remains "up for grabs" [19:22] as it is "enticing and provocative, yet [...] remains elusive" [7:1]. In 2013 Bleecker remarked in terms of his studios own practice "I don't think we've figured it out" and that "studying it, understanding it and trying to devise some of the principles - of what we're calling design fiction - is what we're trying to do" [1]. Adopting a research through design approach $[5,6]$, this doctoral research intends to shed light on the questions raised by Bleecker by researching design fiction, with design fiction.
\end{abstract}

\section{Author Keywords}

Design fiction, design theory, diegetic prototyping

\section{ACM Classification Keywords}

H.5.m. [Information interfaces and presentation]:

Miscellaneous - Design;

\section{CONTEXT}

Technology and network effects pervade society [11] as Toffler's notion of "future shock" [20] becomes more tangible in that we struggle to keep pace with technological change, or as Feenberg puts it "we are more than ever aware of both the promise and the threat of technological advance, [yet] we still lack the intellectual means and political tools for managing progress" [4]. With these points in mind it is understandable why approaches that encourage designers to "act as catalysts

Permission to make digital or hard copies of part or all of this work for personal or classroom use is granted without fee provided that copies are not made or distributed for profit or commercial advantage and that copies bear this notice and the full citation on the first page. Copyrights for thirdparty components of this work must be honored. For all other uses, contact the Owner/Author.

Copyright is held by the owner/author(s).

$C \& C^{\prime} 15$, June 22-25, 2015, Glasgow, United Kingdom

ACM 978-1-4503-3598-0/15/06.

http://dx.doi.org/10.1145/2757226.2764763 for public debate and discussion about the kinds of futures people really want" [3:6] become increasingly attractive and relevant. Futurism and design futures are by no means new concepts and have existed in varying forms, ranging from fascist Italian futurism, through early science fiction, to radical design [cf. 3]. However, design fiction exhibits a strong interdisciplinary grounding that covers the social sciences [2], media studies [10], fine art [3] and the corporate world $[8,9]$. These theoretical underpinnings are combined with accessible and evocative ways of communicating them (oftentimes with film, though frequently straying into other media as well). This combination of a strong and diverse theoretical grounding, along with compelling communication tools, makes design fiction a powerful and flexible tool that can open up discursive spaces. Design can meaningfully utilise these spaces in order to move society towards more preferable futures.

\section{RESEARCH THROUGH DESIGN}

This project adopts a research through design approach to making a contribution to knowledge about design fiction. Being a relatively new term with only a handful of texts referring to design fiction theory, the corpus of literature on the subject is not sufficient to build meaningful rhetoric based on discourse alone. Instead this research builds on the work for Frayling [5] and considers the multidimensional, and reciprocal, relationship that research, art, science, and design have with each other. Relevant and available discourse is considered in terms of research into design fiction while contextual searches for individual instances of design fiction practice are incorporated in terms of research for design fiction.

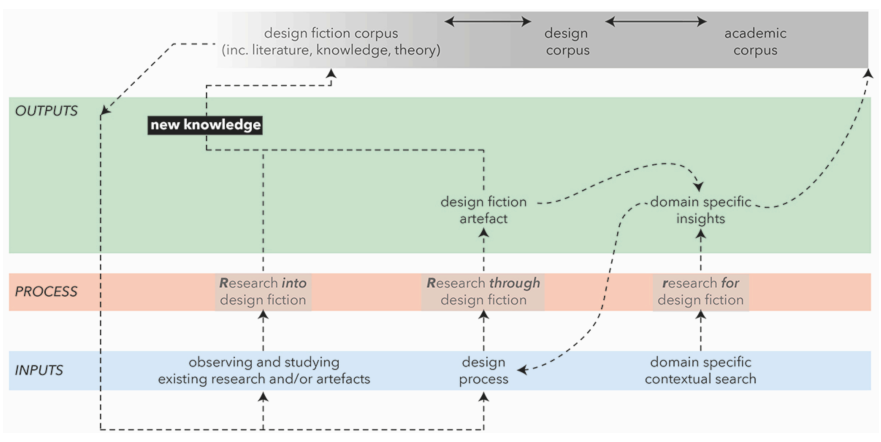

Figure 1. Research through, into and for design fiction. 
Research through design fiction is adopted as the primary means of knowledge production $[6,16]$ and indeed is considered as an epistemic stance in its own right [17]. Reconciling different formulations of research through design with a range of practice is a challenge here. Reflective practice is central to insight generation, however precisely what constitutes suitably rigorous reflective practice is hard to delineate. Similarly, articulating how produced artefacts relate to reflection, and how both relate to 'new knowledge' is difficult to reconcile with scientised perspective of design.

\section{PROGRESS SO FAR AND CHALLENGES TO COME}

With 18 months remaining to consolidate this research into a doctoral thesis, progress is positive although significant challenges remain. Research through design outputs have included: Heating Britain's Homes [12]; A Machine. Learning. [13]; and Care For A Robot (a forthcoming documentary film for Ethicomp 2015). Alongside these practical explorations, complimentary theoretical work has been produced: rhetorical arguments for using design ethnography to make sense of design fictions under the banner "anticipatory ethnography" [14]; reviews of literature in order to disambiguate design fiction rhetoric and provide a "pragmatics framework" [16]; an application of anticipatory ethnography [15]. However two issues broadly cut across these outputs: first, is the challenge of reconciling differing perceptions on research through design as epistemology, a task made more complex by the diversity of design fiction's potential forms [16]. The second challenge relates to the nature of doctoral theses. Should this thesis reflect the topic and be fictional itself? How would being fictional impact upon rigour? How can the reflexivity, central to the research through design, be incorporated meaningfully? As an 'inter-discipline' how should design fiction research negotiate disciplinary silos?

\section{ACKNOWLEDGEMENTS}

Many thanks for Paul Coulton's supervision and for the valuable review comments. This work is funded under the RCUK Digital Economy Programme (Grant Reference $\mathrm{EP} / \mathrm{G} 037582 / 1)$.

\section{REFERENCES}

1. Bleecker, J.Design Fiction: A short essay on design, science, fact and fiction. Near Future Laboratory, (2009).

2. Dourish, P. and Bell, G."Resistance is futile": reading science fiction alongside ubiquitous computing. Personal and Ubiquitous Computing 18, 4 (2014), 769-778.

3. Dunne, A. and Raby, F.Speculative Everything. The MIT Press, London, 2013.
4. Feenberg, A.Transforming technology: A critical theory revisited. Oxford University Press, 2002.

5. Frayling, C.Research in Art and Design. Royal College of Art Research Papers 1, 1 (1993), 1-9.

6. Gaver, W.What should we expect from research through design? Proceedings of the 2012 ACM annual conference on Human Factors in Computing Systems - CHI '12, (2012), 937.

7. Hales, D.Design fictions an introduction and provisional taxonomy. Digital Creativity 24, 1 (2013), 1-10.

8. Johnson, B.Science Fiction Prototypes Or: How I Learned to Stop Worrying about the Future and Love Science Fiction. Intelligent Environments, (2009).

9. Johnson, B.D.Science Fiction Prototyping. Morgan \& Claypool, 2011.

10. Kirby, D.The Future is Now: Diegetic Prototypes and the Role of Popular Films in Generating Realworld Technological Development. Social Studies of Science 40, 1 (2010), 41-70.

11. Lanier, J.Who owns the future. Simon and Schuster, 2013.

12. Lindley, J. and Coulton, P.Modelling Design Fiction: What's The Story? StoryStorm Workshop at ACM Designing Interactive Systems 2014, (2014).

13. Lindley, J. and Potts, R.A Machine. Learning: An example of HCI Prototyping With Design Fiction. Proceedings of the 8th Nordic Conference on Human Computer Interaction, (2014).

14. Lindley, J., Sharma, D., and Potts, R.Anticipatory Ethnography: Design fiction as an input to design ethnography. Ethnographic Praxis in Industry Conference, (2014).

15. Lindley, J. and Sharma, D.An ethnography of the future. Strangers in Strange Lands, (2014).

16. Lindley, J.A pragmatics framework for design fiction. European Academy of Design Conference (In press).

17. Ramirez, R.An epistemology for research through design. Proceedings of the ICSID Design Education Conference, (2009), 1-14.

18. Sterling, B.Shaping Things. The MIT Press, 2005.

19. Tanenbaum, J.Design fictional interactions. Interactions 21, 5 (2014), 22-23.

20. Toffler, A.Future Shock. Random House, 1990. 